\title{
Similarity in connectivity patterns for two gastropod species lacking pelagic larvae
}

\author{
James J. Bell* \\ Centre for Marine Environmental and Economic Research, Victoria University of Wellington, School of Biological Sciences, \\ PO Box 600, Wellington, New Zealand
}

\begin{abstract}
Marine species have a wide range of reproductive strategies that are considered to influence genetic structuring and connectivity between populations. Generally, species without planktonic larvae have reduced dispersal and gene flow between populations compared to species with free-living pelagic larvae. Further divisions exist within non-planktonic species including those exhibiting viviparity and oviparity. Although dispersal potential and population connectivity patterns of these 2 reproductive modes are considered similar, there is little supporting evidence. I examined genetic structuring and gene flow between oviparous and viviparous gastropod populations separated at the same spatial scales (at the same sites). Population genetic structure (using microsatellite data) was compared between island-mainland, mainland-mainland and island-island populations for an egg-laying (Nucella lapillus: oviparous) and a brooding (Littorina saxatilis: ovoviviparous) gastropod species. N. lapillus generally had lower levels of genetic differentiation between populations $\left(R_{\mathrm{ST}}\right.$ ranged between 0.01 and $0.20 ; F_{\mathrm{ST}}$ ranged between 0.01 and 0.17$)$ than L. saxatilis $\left(R_{\mathrm{ST}}\right.$ ranged between 0.02 and $0.21 ; F_{\mathrm{ST}}$ ranged between 0.02 and 0.19 ); these differences were small for all site comparisons. Significant correlations were found between genetic structuring and gene flow patterns for the 2 species, indicating similar dispersal routes and population connectivity patterns. This study shows that it may be possible to generalise connectivity patterns (i.e. dispersal routes) across species lacking pelagic larvae, which may be important for Marine Protected Area network planning.
\end{abstract}

KEY WORDS: Connectivity · Dispersal $\cdot$ Nucella lapillus $\cdot$ Littorina saxatilis $\cdot$ Oviparity $\cdot$ Viviparity Islands $\cdot$ Marine Protected Area

\section{INTRODUCTION}

Marine invertebrates display a spectrum of reproductive strategies that are a major driving force influencing dispersal, gene flow and connectivity between populations (Palumbi 2003). The majority of marine species produce long-lived, free-swimming larvae (planktotrophic) that may normally be expected to disperse widely and link adult populations across broad spatial scales (Thorson 1950), while species that produce short-lived larvae (leciphotrophic) may be expected to have lower levels of gene flow between populations (e.g. Colson \& Hughes 2004). Species without a pelagic larval stage (direct-development) would be expected to have the lowest levels of genetic connec- tivity between populations. Within each of these broad life-history strategy divisions, smaller species-specific differences may also influence dispersal and population genetic structuring (Hohenlohe 2004, Veliz et al. 2006). The majority of studies investigating the roles of different reproductive strategies in determining population connectivity or genetic structuring have compared organisms with planktonic and non-planktonic larvae (e.g. Hellberg 1996, Edmunds \& Potts 1997, Hoskin 1997, Kyle \& Boulding 2000) or short- and longlived planktonic larvae (e.g. Watts \& Thorpe 2006). Little consideration has been given to the way other differences in life-history strategies or reproductive ecology (e.g. reproductive timing, fecundity, larval mortality or egg/sperm longevity) can influence popu- 
lation genetic structuring (but see Cowen et al. 2006), or to whether patterns for species with similar dispersal strategies are consistent across the same spatial scales. Understanding consistencies in structuring and connectivity patterns will be particularly useful in the development of Marine Protected Area (MPA) networks as its unlikely we will be able to examine connectivity patterns of all species in a protected area.

Several reproductive strategies can be identified for species lacking pelagic larvae, including egg brooding with the birth of live young (viviparity), and egg-laying (oviparity). Although these 2 modes have the potential to influence the genetic structure of organisms in different ways, they have often been considered analogous (Grantham et al. 2003). Traditionally, species lacking pelagic larvae have been considered to disperse via adult migration, rafting or drifting (Highsmith 1985, Martel \& Chia 1991). However, whether eggs are brooded internally or laid externally has the potential to further influence dispersal between populations; in oviparous species, egg capsules can be dislodged and transported away from parental populations, potentially resulting in patterns of population connectivity or genetic structuring different from those of viviparous species. It is important to realise that dispersal by rafting or the dislodgement of egg capsules are stochastic processes in the first instance, and therefore differences in the genetic structuring of viviparous and oviparous species might be expected, although once egg capsules are adrift, hydrographic factors may be more predictable (Cowen et al. 2006). To the author's knowledge, there is only one previous study that has directly compared the genetic structure of non-pelagic species (Berger 1973) with differences in parental investment in egg care (oviparity versus viviparity), while most studies have focused on the intuitive differences between pelagic and nonpelagic species, or limited versus long-lived pelagic larvae. Berger (1973) compared the genetic structure of gastropod species with non-pelagic development using allozymes markers and found the presence of local-scale structuring for both Littorina saxatilis and L. obtusata (both have non-pelagic development), although the allele frequencies of the loci studied differed considerably between the species for the same localities where sampling was conducted. Furthermore, the majority of recent genetic studies using fine-scale microsatellite markers have focused on single species, making it difficult to generalise patterns of connectivity for different reproductive modes. Comparisons between different studies are also difficult, even when conducted over similar spatial scales, as different sampling sites are usually compared, which has the potential to confound such comparisons.

In this study I examined the genetic structure of mainland and island populations of 2 species of gastro- pod with no pelagic larval phase to estimate gene flow and genetic differentiation between continuous populations and those separated by unsuitable adult habitat (island-mainland and island-island comparisons) to examine any consistency in genetic structuring and gene flow. Littorina saxatilis (Olivi) is an egg-brooding species (ovoviviparous - brooded eggs are fed from a yolk sac) that gives birth to live young, while Nucella lapillus (L.) lays egg capsules (oviparous) that are cemented to rock surfaces. Both species have been subjects of previous genetic investigations that showed considerable population genetic structuring (e.g. Day 1990, Kirby 2000, Williams et al. 2003, Colson \& Hughes 2004, Rolán-Alvarez et al. 2004, Fernández et al. 2005), often over very small spatial scales for N. lapillus (Rolán et al. 2004). In contrast, several authors (see Colson \& Hughes 2004, Bell \& Okamura 2005) have reported higher levels of gene flow between populations of $N$. lapillus than might be expected for a direct-developing species; this has been accounted for primarily by the rafting of juvenile snails. Rafting has also been suggested as a dispersal mechanism for L. saxatilis. For example, re-colonisation of L. saxatilis to some island habitats after extinction following a toxic algal bloom is thought to have occurred through juvenile rafting (Johannesson \& Johannesson 1995).

Given that both Littorina saxatilis and Nucella lapillus have the potential for rafting, if this is a dispersal mechanism of similar importance for the 2 species, then population genetic structuring is likely to be comparable over similar spatial-scales, but only if reasonably consistent local-scale hydrodynamic conditions exist. Since rafting or drifting will be more important in maintaining gene flow between mainland and island populations compared with gene flow between mainland populations, comparisons of island-mainland and mainland-mainland connectivities should make consistencies in connectivity patterns more apparent. The aim of this study was to investigate differences in genetic differentiation and gene flow between $N$. lapillus and L. saxatilis populations separated by the same geographic distances to examine any consistency in population connectivity (given the similarity in reproductive mode).

\section{MATERIALS AND METHODS}

Species. Littorina saxatilis is a grazing gastropod that is abundant on the upper shores in northern Europe. Fertilisation for this species occurs internally with the embryos (with a yolk sac) held in an internal brood chamber. The juvenile snails crawl out of the brood chamber away from their mother. Nucella lapil- 
lus (L.) is an abundant predatory gastropod occupying rocky intertidal habitats; it has no larval dispersal phase and there is direct-development from egg sacs that are cemented to rocky surfaces following internal fertilisation. Both species occupy similar adult habitats and have low adult migration rates ranging between 3 and $20 \mathrm{~m} \mathrm{yr}^{-1}$.

Study area. Populations were sampled on Inishmaan (Co. Galway coast, Ireland) and Inishbofin (Connemara coast, Ireland) islands, which are 2 Special Areas of Conservation off the coast of western Ireland. Inishmaan is approximately $15 \mathrm{~km}$ offshore, while Inishbofin is about $6 \mathrm{~km}$ from the nearest mainland (Fig. 1). These sites represent different potential scales of isolation located at different distances from the mainland, but are approximately the same land areas $\left(\sim 10 \mathrm{~km}^{2}\right)$. Populations were sampled at 8 locations in total (see Fig. 1), which represented 4 populations on the Irish mainland, 2 populations on the mainland coast nearest Inishmaan (Inveran and Fanore) and 2 populations on the coast nearest Inishbofin (Aughrus More and Cashleen). Two further populations were sampled on each island. Mainland sampling stations were selected to include sites with the closest proximity to the island locations, while island populations were selected such that they were situated as far apart as possible (taking into account suitable habitat for the organisms). Populations were sampled on moderately exposed shores to ensure (for both species) that the same ecotypes were sampled.

Molecular approaches. Tissue was dissected from the feet of Nucella lapillus and Littorina saxatilis and

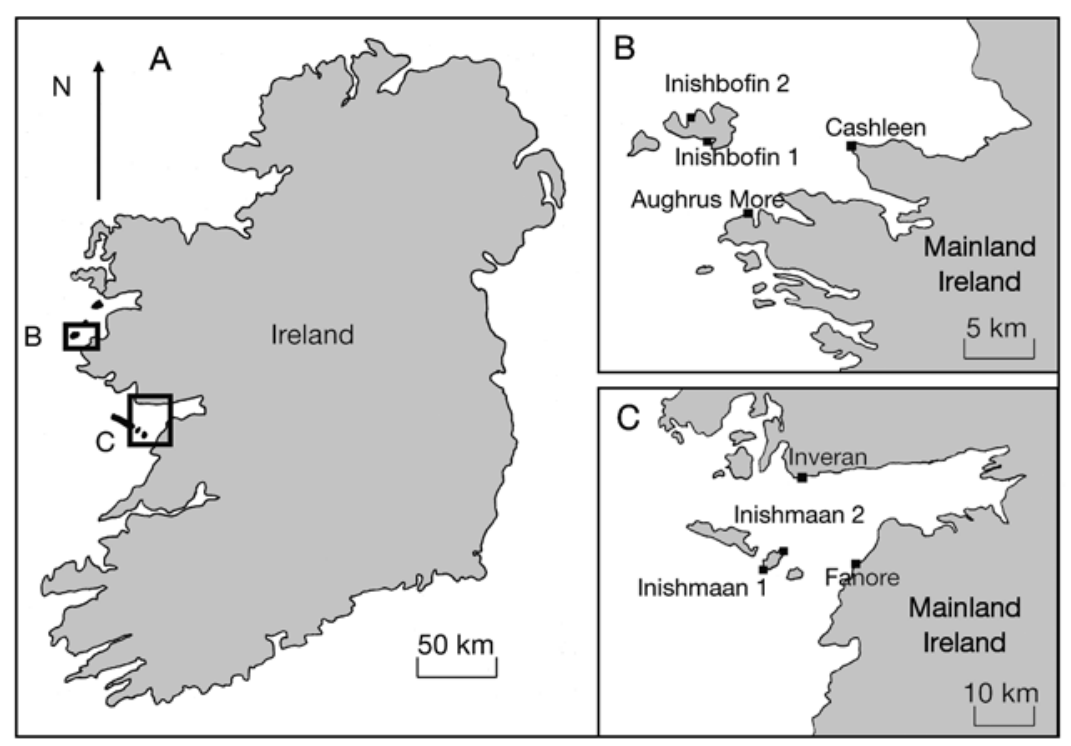

Fig. 1. (A) Locations where populations of Littorina saxatilis and Nucella lapillus were sampled on the Irish coast at (B) Inishbofin and (C) Inishmaan stored in ethanol $(99 \%)$ at $5^{\circ} \mathrm{C}(\mathrm{n}=50$ for each population). DNA was extracted using Sigma DNA extraction kits and stored in TE buffer (at $-20^{\circ} \mathrm{C}$ ). Microsatellite markers developed by Kawai et al. (2001) and Sokolov et al. (2002) were used to characterise the genetic structures of $N$. lapillus and $L$. saxatilis populations, respectively, although PCR conditions and annealing temperatures differed from those published for each species. The microsatellites used for $N$. lapillus were (with annealing temperature in brackets): Nlw 3 $\left(55^{\circ} \mathrm{C}\right)$, Nlw $5\left(56^{\circ} \mathrm{C}\right)$, Nlw $8\left(55^{\circ} \mathrm{C}\right)$, Nlw $11\left(54^{\circ} \mathrm{C}\right)$, and Nlw $13\left(55^{\circ} \mathrm{C}\right)$, while microsatellites Lx12 $\left(58^{\circ} \mathrm{C}\right), \mathrm{Lx} 14$ $\left(60^{\circ} \mathrm{C}\right), \operatorname{Lsax} 20\left(58^{\circ} \mathrm{C}\right)$ and $\operatorname{Lx} 23\left(58^{\circ} \mathrm{C}\right)$ were used in the genetic characterisation of $L$. saxatilis populations. PCR amplification was carried out in a final volume of $20 \mathrm{\mu l}$ containing $5 \mathrm{mM}$ Tris- $\mathrm{HCl}, 10 \mathrm{mM} \mathrm{NaCl}$, $0.01 \mathrm{mM}$ EDTA, $0.1 \mathrm{mM}$ DTT, $5 \%$ glycerol, $0.1 \%$ Triton $^{\circledR} \mathrm{X}-100,1.5 \mathrm{mM} \mathrm{MgCl}{ }_{2}$ (PROMEGA storage buffer A), approximately $10 \mathrm{ng}$ of genomic DNA, $0.8 \mathrm{mM}$ dNTPs, 0.5 units of Taq Polymerase (PROMEGA) and $0.5 \mu \mathrm{M}$ of each primer. Thermal cycling was performed at the following settings for $N$. lapillus: 4 min at $94^{\circ} \mathrm{C}$, 35 thermal cycles of $30 \mathrm{~s}$ at $94^{\circ} \mathrm{C}, 30 \mathrm{~s}$ at the optimal annealing temperature (see above) and $30 \mathrm{~s}$ at $68^{\circ} \mathrm{C}$, and an extra extension step of $8 \mathrm{~min}$ at $68^{\circ} \mathrm{C}$. For L. saxatilis: 5 min at $94^{\circ} \mathrm{C}$ and 35 thermal cycles with $40 \mathrm{~s}$ at $94^{\circ} \mathrm{C}, 1 \mathrm{~min}$ at the optimal annealing temperature (see above), $30 \mathrm{~s}$ at $72^{\circ} \mathrm{C}$ and an extra extension step of $8 \mathrm{~min}$ at $72^{\circ} \mathrm{C}$. The presence of PCR products was confirmed on a $3 \%$ agarose gel and genotypes were determined using an ABI Prism 3100 sequencer (forward primers were labelled with either 6-FAM, NED, VIC or HEX fluorescent dyes to allow loci to be analysed simultaneously) and alleles for each microsatellite were scored using GenMapper (ABI).

Genetic analysis. Tests of deviations of genotype frequencies from the Hardy-Weinberg Equilibrium (HWE) and linkage disequilibrium were carried out using the exact tests within the computer program Genepop, with significance levels being determined using the Markov chain method (default settings of 100 batches of 1000 iterations). The significance levels of each test were determined by applying the sequential Bonferroni procedure over each locus within each population. Genetic diversity was calculated for each population as the mean number of alleles per locus $(A)$, the expected proportion of heterozygotes $\left(H_{\mathrm{e}}\right)$, the observed number of heterozygotes and the inbreeding coefficient $\left(F_{\mathrm{IS}}\right)$. 
The genetic structure of populations was assessed using 2 models: the infinite allele model (Kimura \& Crow 1964) and the stepwise mutation model (Kimura \& Ohta 1978). The program Arlequin, Version 2.0 was used to calculate values of $F_{\mathrm{ST}}$ (Weir \& Cockerham 1984 ) and $R_{\mathrm{ST}}$ (Slatkin 1995) and to conduct analysis of molecular variance (AMOVA). Significance levels were determined for the overall values and for population pairwise values after 1000 permutations. An estimation of the number of migrants per generation $(\mathrm{Nm})$ was calculated as:

$$
N m=\frac{1}{4}\left(\frac{1}{X_{\mathrm{ST}}}-1\right)
$$

where $X_{\mathrm{ST}}$ is either $R_{\mathrm{ST}}$ or $F_{\mathrm{ST}}$.

Assignment tests were performed using the online computer program Doh (J. Brzustowski, 'Doh assignment test calculator' available at: www2.biology. ualberta.ca/jbrzusto/Doh.php), which is based on the calculations of Paetkau et al. (1997). This program takes genotypes of individuals from all sampled populations and determines, using an assignment index, the population from which each individual is mostly likely to have originated (see Paetkau et al. 1997). This index can be defined as the highest probability of an individual's genotype in any of the populations. A matrix was constructed (using Doh) of $A_{x, y}$ which is a measure of how much more likely genotypes of individuals sampled in population $x$ are in a population than in population $y$. A similarity dendrogram was produced from these distances using the Drawtree program from the PHYLIP software package (using complete linkage and Canberra distances). Assignment tests were conducted to complement estimation of gene flow via the standard $N m$ approach described above to avoid the numerous assumptions entailed in derivation of $\mathrm{Nm}$ such as constant population size, an infinite number of populations, constant migration rates and population equilibrium.

Mantel tests were used to compare the matrices of pairwise $F_{\mathrm{ST}}$ and $R_{\mathrm{ST}}$ values between the 2 species using the software programme zt to examine the consistency of genetic differences between populations. One-way Analysis of Variance (ANOVA) was used to compare the mean number of alleles per locus between sites.

\section{RESULTS}

\section{Genetic diversity}

The mean number of alleles (Table 1) per locus ranged from 9.2 to 13.0 and from 8 to 12 for Littorina saxatilis and Nucella lapillus, respectively. No signifi-
Table 1. Littorina saxatilis and Nucella lapillus. Genetic diversity of populations. Mean numbers of alleles per locus $( \pm \mathrm{SD})$ $(A)$, observed heterozygosities $\left(H_{0}\right)$, expected heterozygosities $\left(H_{\mathrm{e}}\right)$ and $F_{\mathrm{IS}}$ (inbreeding coefficient) across all microsatellite loci examined at 8 Irish sites ( $\mathrm{n}=50$ at each site). For site descriptions see text

\begin{tabular}{|lcccc|}
\hline & $A$ & $H_{\mathrm{o}}$ & $H_{\mathrm{e}}$ & $F_{\mathrm{IS}}$ \\
\hline Littorina saxatilis & & & & \\
Inishbofin 1 & $9.20( \pm 6.34)$ & 0.50 & 0.59 & 0.03 \\
Inishbofin 2 & $9.50( \pm 5.12)$ & 0.51 & 0.60 & 0.02 \\
Aughrus More & $11.01( \pm 6.60)$ & 0.55 & 0.61 & 0.05 \\
Cashleen & $11.12( \pm 6.67)$ & 0.55 & 0.62 & 0.07 \\
Inishmaan 1 & $9.67( \pm 6.12)$ & 0.52 & 0.59 & 0.05 \\
Inishmaan 2 & $9.75( \pm 6.77)$ & 0.57 & 0.61 & 0.03 \\
Inveran & $13.00( \pm 6.49)$ & 0.51 & 0.56 & 0.04 \\
Fanore & $11.75( \pm 5.63)$ & 0.53 & 0.52 & 0.02 \\
Nucella lapillus & & & & \\
Inishbofin 1 & $8.0( \pm 4)$ & 0.57 & 0.61 & 0.07 \\
Inishbofin 2 & $7.5( \pm 5)$ & 0.59 & 0.64 & 0.06 \\
Aughrus More & $11.0( \pm 4)$ & 0.60 & 0.54 & 0.07 \\
Cashleen & $11.1( \pm 5)$ & 0.67 & 0.61 & 0.08 \\
Inishmaan 1 & $9.8( \pm 5)$ & 0.57 & 0.62 & 0.06 \\
Inishmaan 2 & $9.8( \pm 5)$ & 0.58 & 0.61 & 0.05 \\
Inveran & $12( \pm 5)$ & 0.60 & 0.58 & 0.03 \\
Fanore & $10.8( \pm 6)$ & 0.62 & 0.60 & 0.02 \\
\hline
\end{tabular}

cant differences in the mean number of alleles per locus were found between pairs of sites for each species (ANOVA, $F_{7,393}<1.86, \mathrm{p}>0.05$ ), although lower genetic diversity was found in island populations than in mainland populations of both species. There were no exclusive alleles for either species at any of the sites, and global tests of all data showed no significant departure from HWE, with no population individually departing from HWE. Of all the possible comparisons, there were only 3 locus-site pairs that exhibited significant linkage disequilibrium at the 0.05 significance level for L. saxatilis (Loci $L x 12$ and $L x 14$ at sites IN, IN1, and IB1); 2 N. lapillus locus-site pairs exhibited significant linkage disequilibrium at the 0.05 significance level (Loci Nwl8 and Nwl13 at sites IB1 \& IN1, respectively). Independence amongst loci was therefore assumed. The observed heterozygosity across all loci for each population (Table 1) ranged between 0.50 and 0.57 for L. saxatilis and 0.57 to 0.67 for N. lapillus. The similarity in expected and observed heterozygosities corresponded to low inbreeding coefficients $\left(F_{\mathrm{IS}}\right)$, which were not significantly different from zero at any of the sites for either species.

\section{Genetic differentiation between populations}

Significant heterogeneity in genotypic frequency distribution was found between most pairwise comparisons among populations of both species under both 
the infinite allele $\left(F_{\mathrm{ST}}\right)$ and stepwise mutation $\left(R_{\mathrm{ST}}\right)$ models ( $p<0.001)$ (Table 2$)$. This significant heterogeneity indicated genetic differences between some mainland-mainland and mainland-island sites for both species. Population pairwise comparisons of $F_{\mathrm{ST}}$ values were smaller than $R_{\mathrm{ST}}$, although the same patterns were identified from both measures. According to Wright's (1978) interpretation of $F_{\mathrm{ST}}$ values (which can be considered analogous to $R_{\mathrm{ST}}$ for comparisons), considerable variation occurred in the degree of genetic differentiation between some population pairs.

For Littorina saxatilis, the $R_{\mathrm{ST}}$ values of the 2 populations sampled on Inishmaan and Inishbofin ranged between 0.04 and 0.06, indicating little genetic differentiation (not significantly different from zero). For Inishbofin, comparisons of $R_{\mathrm{ST}}$ between island and mainland (Cashleen and Aughrus More) populations showed moderate, yet significant, levels of genetic differentiation, with values of $R_{\mathrm{ST}}$ ranging between 0.10 and 0.14. A high level of significant genetic differentiation was apparent when comparing Inishbofin populations with those at Inveran and Fanore (where $R_{\mathrm{ST}}$ ranged between 0.12 and 0.17 ). $R_{\mathrm{ST}}$ comparisons between $L$. saxatilis populations on Inishmaan and on the mainland indicated moderate to high levels of genetic differentiation of island populations from all mainland populations $\left(R_{\mathrm{ST}} 0.10\right.$ to 0.17$)$. Low levels of genetic differentiation were found between Aughrus More and Cashleen in comparison with the differentiation between mainland sites and Inishbofin, which are separated by the same geographical distance. Inishmaan is the furthest island from the mainland and had greater genetic differentiation from mainland sites than Inishbofin.

For Nucella lapillus, the lowest levels of genetic differentiation occurred between pairs of populations

Table 2. Littorina saxatilis and Nucella lapillus. Matrix of pairwise comparisons of population genetic differentiation using $F_{\mathrm{ST}}$ (infinite allele model) on the lower diagonal and $R_{\mathrm{ST}}$ (stepwise mutation model) on the upper diagonal. Calculated values of $N m$ (migration rates) are given in parentheses. Shaded cells indicate non-significant pairwise comparisons $(p>0.05)$

\begin{tabular}{|c|c|c|c|c|c|c|c|c|}
\hline & Inishbofin 1 & Inishbofin 2 & $\begin{array}{l}\text { Aughrus } \\
\text { More }\end{array}$ & Cashleen & Inishmaan 1 & Inishmaan 2 & Inveran & Fanore \\
\hline \multicolumn{9}{|l|}{ Littorina saxatilis } \\
\hline Inishbofin 1 & - & $\begin{array}{c}0.06 \\
(3.92)\end{array}$ & $\begin{array}{c}0.13 \\
(1.67)\end{array}$ & $\begin{array}{c}0.14 \\
(1.54)\end{array}$ & $\begin{array}{c}0.15 \\
(1.42)\end{array}$ & $\begin{array}{c}0.14 \\
(1.54)\end{array}$ & $\begin{array}{c}0.15 \\
(1.42)\end{array}$ & $\begin{array}{c}0.18 \\
(1.04)\end{array}$ \\
\hline Inishbofin 2 & $\begin{array}{c}0.04 \\
(6.00)\end{array}$ & - & $\begin{array}{c}0.14 \\
(1.54)\end{array}$ & $\begin{array}{c}0.10 \\
(2.25)\end{array}$ & $\begin{array}{c}0.18 \\
(1.14)\end{array}$ & $\begin{array}{c}0.20 \\
(1.00)\end{array}$ & $\begin{array}{c}0.12 \\
(1.83)\end{array}$ & $\begin{array}{c}0.17 \\
(1.22)\end{array}$ \\
\hline Aughrus More & $\begin{array}{c}0.07 \\
(3.32)\end{array}$ & $\begin{array}{c}0.10 \\
(2.25)\end{array}$ & - & $\begin{array}{c}0.02 \\
(12.25)\end{array}$ & $\begin{array}{c}0.16 \\
(1.31)\end{array}$ & $\begin{array}{c}0.18 \\
(1.14)\end{array}$ & $\begin{array}{c}0.09 \\
(1.53)\end{array}$ & $\begin{array}{c}0.16 \\
(1.31)\end{array}$ \\
\hline Cashleen & $\begin{array}{c}0.11 \\
(2.03)\end{array}$ & $\begin{array}{c}0.11 \\
(2.03)\end{array}$ & $\begin{array}{c}0.02 \\
(12.25)\end{array}$ & - & $\begin{array}{c}0.14 \\
(1.54)\end{array}$ & $\begin{array}{c}0.13 \\
(1.67)\end{array}$ & $\begin{array}{c}0.07 \\
(3.32)\end{array}$ & $\begin{array}{c}0.19 \\
(1.07)\end{array}$ \\
\hline Inishmaan 1 & $\begin{array}{c}0.12 \\
(1.83)\end{array}$ & $\begin{array}{c}0.14 \\
(1.54)\end{array}$ & $\begin{array}{c}0.14 \\
(1.54)\end{array}$ & $\begin{array}{c}0.13 \\
(1.67)\end{array}$ & - & $\begin{array}{c}0.04 \\
(6.00)\end{array}$ & $\begin{array}{c}0.14 \\
(1.54)\end{array}$ & $\begin{array}{c}0.16 \\
(1.31)\end{array}$ \\
\hline Inishmaan 2 & $\begin{array}{c}0.10 \\
(2.25)\end{array}$ & $\begin{array}{c}0.16 \\
(1.31)\end{array}$ & $\begin{array}{c}0.10 \\
(2.25)\end{array}$ & $\begin{array}{c}0.11 \\
(2.02)\end{array}$ & $\begin{array}{c}0.02 \\
(12.25)\end{array}$ & - & $\begin{array}{c}0.17 \\
(1.22)\end{array}$ & $\begin{array}{c}0.10 \\
(2.25)\end{array}$ \\
\hline Inveran & $\begin{array}{c}0.11 \\
(2.02)\end{array}$ & $\begin{array}{c}0.10 \\
(2.25)\end{array}$ & $\begin{array}{c}0.05 \\
(4.75)\end{array}$ & $\begin{array}{c}0.05 \\
(4.75)\end{array}$ & $\begin{array}{c}0.13 \\
(1.67)\end{array}$ & $\begin{array}{c}0.15 \\
(1.42)\end{array}$ & - & $\begin{array}{c}0.21 \\
(0.94)\end{array}$ \\
\hline Fanore & $\begin{array}{c}0.17 \\
(1.22)\end{array}$ & $\begin{array}{c}0.15 \\
(1.42)\end{array}$ & $\begin{array}{c}0.14 \\
(1.54)\end{array}$ & $\begin{array}{c}0.15 \\
(1.42)\end{array}$ & $\begin{array}{c}0.04 \\
(6.00)\end{array}$ & $\begin{array}{c}0.06 \\
(3.92)\end{array}$ & $\begin{array}{c}0.19 \\
(1.07)\end{array}$ & - \\
\hline \multicolumn{9}{|l|}{ Nucella lapillus } \\
\hline Inishbofin 1 & - & $\begin{array}{c}0.01 \\
(24.75)\end{array}$ & $\begin{array}{c}0.09 \\
(2.53)\end{array}$ & $\begin{array}{c}0.09 \\
(2.53)\end{array}$ & $\begin{array}{c}0.13 \\
(1.67)\end{array}$ & $\begin{array}{c}0.11 \\
(2.02)\end{array}$ & $\begin{array}{c}0.08 \\
(2.88)\end{array}$ & $\begin{array}{c}0.15 \\
(1.42)\end{array}$ \\
\hline Inishbofin 2 & $\begin{array}{c}0.01 \\
(24.75)\end{array}$ & - & $\begin{array}{c}0.09 \\
(2.53)\end{array}$ & $\begin{array}{c}0.10 \\
(2.25)\end{array}$ & $\begin{array}{c}0.16 \\
(1.31)\end{array}$ & $\begin{array}{c}0.13 \\
(1.67)\end{array}$ & $\begin{array}{c}0.07 \\
(3.32)\end{array}$ & $\begin{array}{c}0.15 \\
(1.42)\end{array}$ \\
\hline Aughrus More & $\begin{array}{c}0.06 \\
(3.92)\end{array}$ & $\begin{array}{c}0.09 \\
(2.53)\end{array}$ & - & $\begin{array}{c}0.01 \\
(24.75)\end{array}$ & $\begin{array}{c}0.15 \\
(1.42)\end{array}$ & $\begin{array}{c}0.11 \\
(2.02)\end{array}$ & $\begin{array}{c}0.05 \\
(4.75)\end{array}$ & $\begin{array}{c}0.17 \\
(1.22)\end{array}$ \\
\hline Cashleen & $\begin{array}{c}0.09 \\
(2.53)\end{array}$ & $\begin{array}{c}0.08 \\
(2.88)\end{array}$ & $\begin{array}{c}0.01 \\
(24.75)\end{array}$ & - & $\begin{array}{c}0.13 \\
(1.67)\end{array}$ & $\begin{array}{c}0.11 \\
(2.02)\end{array}$ & $\begin{array}{c}0.06 \\
(3.92)\end{array}$ & $\begin{array}{c}0.16 \\
(1.31)\end{array}$ \\
\hline Inishmaan 1 & $\begin{array}{c}0.10 \\
(2.25)\end{array}$ & $\begin{array}{c}0.13 \\
(1.67)\end{array}$ & $\begin{array}{c}0.13 \\
(1.67)\end{array}$ & $\begin{array}{c}0.11 \\
(2.02)\end{array}$ & - & $\begin{array}{c}0.02 \\
(12.25)\end{array}$ & $\begin{array}{c}0.13 \\
(1.67)\end{array}$ & $\begin{array}{c}0.10 \\
(2.25)\end{array}$ \\
\hline Inishmaan 2 & $\begin{array}{c}0.09 \\
(2.53)\end{array}$ & $\begin{array}{c}0.13 \\
(1.67)\end{array}$ & $\begin{array}{c}0.09 \\
(2.53)\end{array}$ & $\begin{array}{c}0.09 \\
(2.53)\end{array}$ & $\begin{array}{c}0.01 \\
(24.65)\end{array}$ & - & $\begin{array}{c}0.11 \\
(2.02)\end{array}$ & $\begin{array}{c}0.07 \\
(3.32)\end{array}$ \\
\hline Inveran & $\begin{array}{c}0.07 \\
(3.32)\end{array}$ & $\begin{array}{c}0.09 \\
(2.53)\end{array}$ & $\begin{array}{c}0.04 \\
(6.00)\end{array}$ & $\begin{array}{c}0.03 \\
(8.08)\end{array}$ & $\begin{array}{c}0.12 \\
(1.83)\end{array}$ & $\begin{array}{c}0.13 \\
(1.67)\end{array}$ & - & $\begin{array}{c}0.20 \\
(1.00)\end{array}$ \\
\hline Fanore & $\begin{array}{c}0.14 \\
(1.54)\end{array}$ & $\begin{array}{c}0.12 \\
(1.83)\end{array}$ & $\begin{array}{c}0.12 \\
(1.83)\end{array}$ & $\begin{array}{c}0.13 \\
(1.67)\end{array}$ & $\begin{array}{c}0.05 \\
(4.75)\end{array}$ & $\begin{array}{c}0.05 \\
(4.75)\end{array}$ & $\begin{array}{c}0.17 \\
(1.22)\end{array}$ & - \\
\hline
\end{tabular}


inhabiting the 2 islands (i.e IM1 \& IM2; IB1 \& IB2). Inishbofin populations had moderate and significant genetic differentiation $\left(R_{\mathrm{ST}} 0.09\right.$ to 0.10$)$ from those on the nearest mainland (Aughrus More and Cashleen), but high levels of genetic differentiation from Fanore $\left(R_{\mathrm{ST}}=0.15\right)$. For Inishmaan, there were moderate levels of genetic differentiation $\left(R_{\mathrm{ST}} 0.07\right.$ to 0.13$)$ between island populations and Inveran, Aughrus More and Cashleen, but low to moderate genetic differentiation from Fanore populations. Low levels of genetic differentiation $\left(R_{\mathrm{ST}}<0.05\right)$ occurred between Cashleen and Aughrus More, with both sites having moderate differentiation from Inveran populations. However, all sites had significantly higher levels of genetic differentiation $\left(R_{\mathrm{ST}}>0.15\right)$ from Fanore populations, with the exception of sites on Inishmaan $\left(R_{\mathrm{ST}} 0.07\right.$ to 0.10$)$. The level of genetic differentiation between Cashleen and Aughrus More was less than levels between these mainland sites and Inishbofin.

A hierarchical analysis of genetic diversity based on the variance of allele frequencies revealed significant levels of genetic variance among Littorina saxatilis and Nucella lapillus populations (Table 3). The AMOVA showed that approximately $14.23 \%$ and $11.48 \%$ of the total microsatellite DNA variation was explained by the variance among populations for $L$. saxatilis and $N$. lapillus, respectively, with the largest proportion of the variance attributable to the individuals within the total population. Each component of the genetic variance was significantly different from zero $(p<0.001)$.

The dendrograms produced by Drawtree based on assignment indices (Fig. 2) indicated considerable genetic differentiation between some populations, but similar patterns across species. Both species had small levels of genetic differentiation between the 2 populations sampled on Inishmaan (IM1 \& IM2) and Inishbofin (IB1 \& IB2), with assignment indices following similar patterns to those identified by $F_{\mathrm{ST}}$ and $R_{\mathrm{ST}}$ values. Populations of both Littorina saxatilis and Nucella

Table 3. Littorina saxatilis and Nucella lapillus. Hierarchical Analysis of Molecular Variance (AMOVA) based on the variance of allele frequencies between 8 populations of each species

\begin{tabular}{|lccccc|}
\hline $\begin{array}{l}\text { Source of } \\
\text { variation }\end{array}$ & $\begin{array}{c}\text { Degrees } \\
\text { of } \\
\text { freedom }\end{array}$ & $\begin{array}{c}\text { Sum } \\
\text { of } \\
\text { squares }\end{array}$ & $\begin{array}{c}\text { Variance } \\
\text { compo- } \\
\text { nents }\end{array}$ & $\begin{array}{c}\text { Percen- } \\
\text { tage of } \\
\text { variance }\end{array}$ & $\begin{array}{c}\text { Signi- } \\
\text { ficance } \\
\text { level }\end{array}$ \\
\hline Littorina saxatilis & & & & & \\
$\begin{array}{l}\text { Among populations } \\
\text { Between populations }\end{array}$ & 792 & 99.471 & 0.155 & 14.23 & $<0.001$ \\
Total & 799 & 699.021 & 1.391 & & $<0.001$ \\
Nucella lapillus & & & & & \\
$\begin{array}{l}\text { Among populations } \\
\text { Between populations }\end{array}$ & 7 & 70.627 & 0.149 & 11.48 & $<0.001$ \\
Total & 799 & 542.467 & 1.149 & 88.52 & $<0.001$ \\
\hline
\end{tabular}

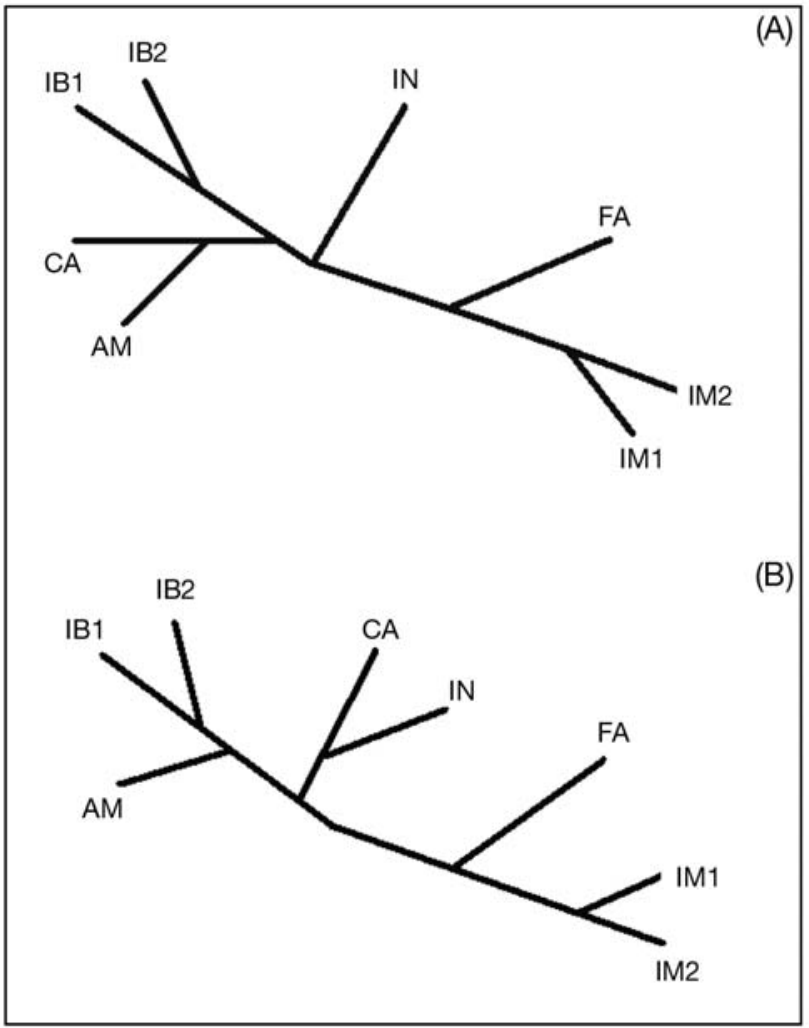

Fig. 2. Littorina saxatilis and Nucella lapillus. Similarity dendrogram (clustering using Canberra distance and complete linkage) constructed using Drawtree in the PHYLIP software package (redrawn to scale) based on a distance matrix calculated from assignment indices for populations of (A) L. saxatilis and (B) N. lapillus; IB1: Inishbofin 1, IB2: Inishbofin 2, IN: Inveran, AM: Aughrus More, CA: Cashleen, FA: Fanore, IM1: Inishmaan 1, IM2: Inishmaan 2. The distances between sites indicate relative genetic differentiation

lapillus at Cashleen and Aughrus More had less differentiation from Inishbofin sites than other mainland sites, while Inishmaan sites had greater genetic differentiation from Inveran than from Fanore. There was further evidence for a genetic break between Inveran and Fanore (north and south of Galway Bay). For N. lapillus, the Inveran population had a genetic structure more similar to those of Cashleen and Aughrus More, which are more geographically distant than Fanore. This pattern was not so distinct for $L$. saxatilis (the Inveran population had similar levels of genetic differentiation from Fanore, Cashleen and Aughrus More). The greatest levels of genetic differentiation were between populations of both species inhabiting the 2 islands (Inish- 
maan and Inishbofin), with levels being considerably greater than any other population comparisons (this was not obvious from $F_{\mathrm{ST}} / R_{\mathrm{ST}}$ values).

\section{Gene flow between populations}

The estimated number of migrants $(\mathrm{Nm})$ between the pairs of Littorina saxatilis populations varied considerably between sites (Table 2), with values based on $R_{\mathrm{ST}}$ ranging from 0.94 (Fanore and Inveran) to 12.25 (Aughrus More and Cashleen), while Nm values ranged from 1.00 (Fanore and Inveran) to 24.75 (IB1 and IB2) for Nucella lapillus. Values calculated from $R_{\mathrm{ST}}$ were lower than those calculated from $F_{\mathrm{ST}}$. The highest levels of gene flow for both species were between the geographically closest sites (IB1 \& IB2, IM1 \& IM2, Aughrus More \& Cashleen), with the exception of Fanore and Inveran. At Inishbofin, levels of gene flow with Aughrus More were only slightly higher than for Cashleen; the lowest levels of gene flow were with Fanore. Inishmaan populations had higher levels of gene flow with Fanore populations than with Inveran. Gene flows between mainland sites Aughrus More and Cashleen were higher than between the mainland sites and Inishbofin. The level of gene flow between Inveran and Fanore was also much lower than between Fanore and Inishmaan populations. However, higher levels of gene flow were seen between Inveran and Inishbofin mainland sites (Aughrus More \& Cashleen) than with Fanore.

\section{Species comparisons}

Only one population comparison out of a total of 28 showed lower $R_{\mathrm{ST}}$ and $F_{\mathrm{ST}}$ values for Littorina saxatilis than for Nucella lapillus; the single exception was not consistent between $R_{\mathrm{ST}}$ and $F_{\mathrm{ST}}$. Therefore higher levels of $F_{\mathrm{ST}}, R_{\mathrm{ST}}$ and lower $\mathrm{Nm}$ values were generally found between $L$. saxatilis populations than between N. lapillus populations. Across all site pairwise comparisons, the mean $\pm \mathrm{SE}$ of $F_{\mathrm{ST}}$ was $0.09 \pm 0.01$ for $N$. lapillus and $0.11 \pm 0.01$ for $L$. saxatilis. The mean $R_{\mathrm{ST}}$ value was $0.13 \pm 0.01$ for $L$. saxatilis and 0.11 \pm 0.01 for $N$. lapillus. Plots by site of $N$. lapillus $F_{\mathrm{ST}}$ and $R_{\mathrm{ST}}$ values against $L$. saxatilis $F_{\mathrm{ST}}$ and $R_{\mathrm{ST}}$ values (Fig. 3) showed strong positive correlations for both estimators of genetic difference, which indicates similar overall genetic structuring across the populations of both species, even though slightly greater levels of genetic differentiation occurred between $L$. saxatilis populations. Mantel tests (used to compare the $F_{\mathrm{ST}}$ and $R_{\mathrm{ST}}$ matrices) showed a significant positive corre-

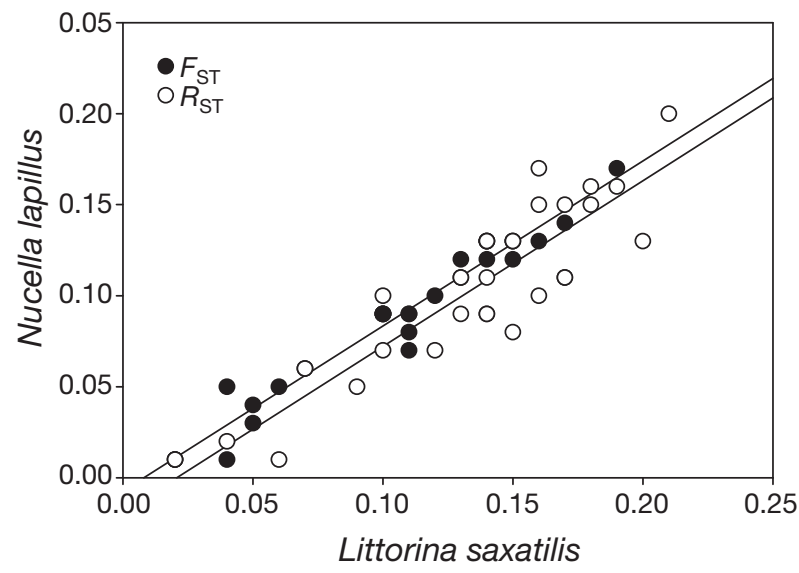

Fig. 3. Littorina saxatilis and Nucella lapillus. Plots of population pairwise comparisons of $N$. lapillus $F_{\mathrm{ST}}$ and $R_{\mathrm{ST}}$ values against $L$. saxatilis $F_{\mathrm{ST}}$ and $R_{\mathrm{ST}}$ values (for the same population comparisons). Pearson's correlation (fitted lines are shown) $>0.89, \mathrm{p}<0.001, \mathrm{df}=27$

lation ( $\mathrm{r}>0.089, \mathrm{p}<0.001,10000$ permutations) between the 2 species, thereby demonstrating consistent genetic differences between the 2 species across the sites. It was not possible to statistically compare the linear relationships between $F_{\mathrm{ST}}$ and $R_{\mathrm{ST}}$ for the 2 species because the data did not meet the assumption of independence.

\section{DISCUSSION}

My research highlights consistent patterns of genetic structuring between 2 species of gastropod lacking a pelagic larval dispersal phase, but with different levels of parental care. Strikingly similar results were seen in the local genetic structuring of both species, despite the expected stochastic nature of rafting and the potential for an egg-laying species to have greater reliance on egg capsule rafting. Furthermore, potential island-isolation did not result in any consistent differences between the species, further illustrating similarity in dispersal routes, reliance on rafting and the apparent consistency of the rafting process. Although differences in the dispersal potentials of planktonic versus non-planktonic species have been well described (Hellberg 1996, Edmunds \& Potts 1997, Hoskin 1997, Kyle \& Boulding 2000), this is the first study to identify consistent patterns of genetic structuring for local-scale mainland-island, island-island and mainland-mainland populations of brooding and egg-laying species over the same spatial-scales using highly polymorphic neutral microsatellite markers. 


\section{Similarity in population genetic structure between species}

Berger (1973) reported similar results when comparing sympatric Littorina saxatilis and Littorina obtusata (also an egg laying species) populations in an earlier allozyme study (using 3 loci), finding both species had local-scale patterns of geographic structuring for coastal populations, contrasting with L. littorea, which has a long-lived planktonic larvae; however, no consistent geographic differentiation patterns for the specific allozyme loci used in the study were found between L. saxatilis and L. obtusata, possibly as a result of local selection processes. Furthermore, Berger (1973) did not estimate overall genetic differentiation or gene flow between populations, and only populations connected along the coast were considered (therefore stepping-stone gene flow was assumed). In my study, consistent local-scale genetic structuring was found for the 2 species, including between open stretches of water, which is perhaps surprising given the stochastic nature of drifting/rafting and egg dislodgement as dispersal mechanisms that might be expected to result in different structuring patterns. This suggests that the direction of dispersal is relatively consistent for both species, and that both species are probably dependent on rafting dispersal to the same degree, although the actual level of rafting dispersal remains undefined. Unfortunately, hydrographic data that might help explain the similarity in genetic structuring for the 2 species are not available for the local area.

Despite the potential for rafting, neither species used in this study has yet been found on rafting material (e.g. algae), which is surprising given their numerical abundance and widespread occurrence on rocky shores across the UK and northern Europe (including islands); dispersal for these species can only be inferred from other evidence. Two drifting Nucella ostrina (a north American species previously named $N$. emarginata) were found in the intertidal zone by Martel \& Chia (1991), leading Gosselin \& Chia (1995) to conclude that although such dispersal events may be rare, they are likely to result in significant and important gene flow between populations. Colson \& Hughes (2004) reported that re-colonising individuals of $N$. lapillus into areas where this species had gone locally extinct (following tributyltin contamination) originated from different populations, indicating recruitment from a variety of sources with populations not being solely dependent on stepping-stone gene flow. There is also indirect evidence for high levels of dispersal in Littorina saxatilis, which was found to re-colonise some islands (but only a low proportion) after a period of only 4 yr following local population extinction caused by a toxic algal bloom (Johannesson \& Johannesson 1995).

\section{Local barriers to gene flow}

Both Nucella lapillus and Littorina saxatilis had higher levels of genetic differentiation between mainland-island populations than between island-island or mainland-mainland populations (with the exception of Fanore and Inveran) indicating, that as expected, a lack of suitable adult habitat between sites is a major driving force influencing dispersal for species lacking pelagic larvae, although it does not appear to result in complete isolation.

The genetic data for both species indicated a strong barrier to gene flow between the sites north of Galway Bay and Fanore (south of Galway Bay) with much lower levels of gene flow between these populations than others separated by the same spatial scales, although there were relatively high levels of gene flow between the Inishmaan sites and the mainland sites comparable to those between Inishbofin and its closest mainland. The area between Fanore and Inveran is not continuous adult habitat (areas of soft sediment are present) and although this may explain some of the genetic differentiation (Johnson \& Black 1998), it is unlikely to explain it all; there was twice as much gene flow between Inishmaen and these 2 mainland sites as there was between Fanore and Inveran, even though all the sites are approximately equidistant. Further explanations may include a salinity cline between these sites from freshwater input or local hydrographic conditions (possibly due to freshwater flow from Galway Bay) inhibiting rafting or the movement of dislodged egg capsules between these sites (Swearer et al. 1999, Hellberg et al. 2002).

The largest population differentiation identified from assignment indices (rather than based on $F_{\mathrm{ST}}$ and $R_{\mathrm{ST}}$ values) occurred between the 2 different islands, irrespective of species (Fig. 2). These sites are not the most geographically distant, but the probability of rafting individuals (from relatively small population sizes) or dislodged egg-capsules moving between island populations is likely to be much less than between mainland-island and mainland-mainland sites. Furthermore, there is no possibility of adult migration directly between these 2 sites.

It is important to note that compared to many other microsatellite studies, the actual levels of genetic differentiation between Littorina saxatilis and Nucella lapillus populations were considerably higher than reported for species with pelagic larvae, which typically have $R_{\mathrm{ST}} / F_{\mathrm{ST}}$ values $<0.05$, often over much large spatial-scales than the present study (e.g. see Colson \& Hughes 2004 for a mini-review). These differences between pelagic and non-pelagic dispersers are also consistent across other molecular marker studies (e.g. Hellberg 1996, Edmunds \& Potts 1997, Hoskin 1997, Kyle \& Boulding 
2000, Watts \& Thorpe 2006). The levels of genetic differentiation (reported in the present study) between populations separated by continuous habitat are consistent with those reported over similar spatial-scales by RolánAlvarez et al. (2004), giving confidence to the estimates of gene flow and genetic differentiation I obtained.

\section{Dispersal consequences of viviparity versus oviparity}

There was some evidence for differences in the gene flow between the 2 species; Nucella lapillus appeared to have less genetic differentiation between populations than Littorina saxatilis. Despite the consistency of the between site comparison results, some caution must be exercised when interpreting the differences between these 2 species, since they were very small and may be attributable to a number of factors other than alternative reproductive strategies. Furthermore, it was not possible to statistically compare the linear relationships between $F_{\mathrm{ST}}$ and $R_{\mathrm{ST}}$ or pairwise differences for the 2 species because the data did not meet the assumption of independence. Other possible explanations for the differences between species include (1) differences in the adult migration rates between species, (2) differences in rafting dispersal rates, (3) geological history of colonisation, (4) selection, although care was taken to ensure the same species ecotypes were sampled at each site because genetic differences have previously been identified between ecotypes (Rolán et al. 2004, Fernández et al. 2005); furthermore, there is no evidence to suggest any of the microsatellite loci used in this study are under selection, (5) habitat differences, since N. lapillus is common on the middle and lower intertidal, whereas L. saxatilis occurs on the upper shore, meaning that the species have potentially different access to rafts (e.g. algae), and (6) the number of loci used was relatively low (4 and 5 for L. saxatilis and N. lapillus, respectively), and they were different between species (since these markers are generally species-specific), which may provide some resolution problems in the data interpretation.

\section{Conclusions}

The results of my study, together with those from previous research (e.g. Johannesson \& Johannesson 1995, Colson \& Hughes 2004, Bell \& Okamura 2005) indicate that relatively high levels of dispersal can occur between populations of Littorina saxatilis and Nucella lapillus, particularly over spatial scales of $10^{4} \mathrm{~m}$. The similarity in the local-scale genetic structuring of these 2 species across the sites indicates that there are similar dominant dispersal processes for both species, including between sites that are separated by unsuitable habitat. My study illustrates that it may be possible to infer genetic structuring patterns/dispersal routes of one species from another (if they have similar life-history traits and dispersal mechanisms), since overall structure was very similar for the 2 species. With increasing interest in population connectivity, particularly with respect to the development of MPA networks, modelling studies to investigate larval exchange (e.g. spillover) and establish connectivity patterns need to integrate multi-species information and require a full understanding of the key biological and physical processes involved in dispersal and population dynamics. Since it is very unlikely that dispersal and connectivity information can be obtained for all species within protected areas, inferring patterns based on similar species-traits may prove useful in MPA network planning and management.

Acknowledgements. I thank the Irish Heritage Council (grant number 2004:13971) and the Nuffield Foundation for providing financial assistance. I am also grateful to H. Orr, H. Cambell and K. Skot for assistance in processing samples, while C. Shaw assisted with field work. Permission to collect samples from the island sites was given by the Irish Wildlife Service.

\section{LITERATURE CITED}

Bell JJ, Okamura B (2005) Low genetic diversity in a marine nature reserve: re-evaluating diversity criteria in reserve design. Proc R Soc Lond B Biol Sci 272:1067-1074

Berger EM (1973) Gene-enzyme variation in three sympatric species of Littorina. Biol Bull 145:83-90

Colson I, Hughes RN (2004) Rapid recovery of genetic diversity of dogwhelk (Nucella lapillus L.) populations after local extinction and recolonization contradicts predictions from life-history characteristics. Mol Ecol 13:2223-2233

Cowen RK, Paris CB, Srinivasan A (2006) Scaling of connectivity in marine populations. Science $311: 522-527$

Day AJ (1990) Microgeographic variation in allozyme frequencies in relation to the degree of exposure to wave action in the dogwhelk Nucella lapillus (L.) (Prosobranchia: Muricacea). Biol J Linn Soc 40:245-261

Edmunds S, Potts DC (1997) Population genetic structure in brooding sea anemones (Epiactis spp.) with contrasting reproductive modes. Mar Biol 127:485-498

Fernández J, Galindo J, Fernández B, Pérez-Figueroa A, Caballero A, Rolán-Alvarez E (2005) Genetic differentiation and estimation of effective population size and migration rates in two sympatric ecotypes of the marine snail Littorina saxatilis. J Hered 96:460-464

Gosselin LA, Chia F (1995) Distribution and dispersal of early juvenile snails: effectiveness of intertidal microhabitats as refuges and food sources. Mar Ecol Prog Ser 128:213-223

Grantham BA, Eckert GL, Shanks AL (2003) Dispersal potential of marine invertebrates in diverse habitats. Ecol Appl 13:108-116

Hellberg ME (1996) Dependence of gene flow on geographic distance in two solitary corals with different larval dispersal capabilities. Evolution 50:1167-1175 
Hellberg ME, Burton RS, Neigel JE, Palumbi SR (2002) Genetic assessment of connectivity among marine populations. Bull Mar Sci 70:273-290

Highsmith RC (1985) Floating and algal rafting as potential dispersal mechanisms in brooding invertebrates. Mar Ecol Prog Ser 25:169-179

Hohenlohe PA (2004) Limits to gene flow in marine animals with planktonic larvae: models of Littorina species around Point Conception, California. Biol J Linn Soc 82:169-187

Hoskin MG (1997) Effects of contrasting modes of larval development on the genetic structures of populations of three species of prosobranch gastropods. Mar Biol 127: 647-656

Johannesson K, Johannesson B (1995) Dispersal and population expansion in a direct developing marine snail (Littorina saxatilis) following a severe population bottleneck. Hydrobiologia 309:173-180

Johnson MS, Black R (1998) Effects of isolation by distance and geographical discontinuity on genetic subdivision of Littorina cingulata. Mar Biol 132:295-303

Kawai K, Hughes RN, Takenaka O (2001) Isolation and characterization of microsatellite loci in the marine gastropod Nucella lapillus. Mol Ecol Notes 1:270-272

Kimura M, Crow J (1964) The number of alleles that can be maintained in a finite allele population. Genetics 49: $725-738$

Kimura M, Ohta T (1978) Stepwise mutation model and distribution of allelic frequencies in a finite population. Proc Natl Acad Sci USA 75:2868-2872

Kirby RR (2000) An ancient transpecific polymorphism shows extreme divergence in a multitrait cline in an intertidal snail (Nucella lapillus (L.). Mol Biol Evol 17:1816-1825

Kyle CJ, Boulding EG (2000) Comparative population genetic structure of marine gastropods (Littorina spp.) with and without pelagic larval dispersal. Mar Biol 137:835-845

Martel A, Chia FS (1991) Drifting and dispersal of small bivalves and gastropods with direct development. J Exp Mar Biol Ecol 150:131-147

Paetkau D, Waits LP, Clarkson PL, Craighead L, Strobeck C (1997) An empirical evaluation of genetic distance statis-

Editorial responsibility: Otto Kinne, Oldendorf/Luhe, Germany tics using microsatellite data from bear (Ursidae) populations. Genetics 147:1943-1957

Palumbi SR (2003) Population genetics, demographic connectivity, and the design of marine reserves. Ecol Appl 13: 146-158

Rolán E, Guerra-Varela J, Colson I, Hughes RN, RolánAlvarez E (2004) Morphological and genetic analysis of two sympatric morphs of the dogwhelk Nucella lapilIus (Mollusca, Neogastropoda) from Galicia (NW Spain). J Molluscan Stud 70:179-185

Rolán-Alvarez E, Carball M, Galindo J, Morán Fernández P and others (2004) Nonallopatric and parallel origin of local reproductive barriers between two snail ecotypes. Mol Ecol 13:3415-3424

Slatkin M (1995) A measure of population subdivision based on microsatellite allele frequencies. Genetics 139:457-462

Sokolov EP, Sokolova IM, Pörtner HO (2002) Polymorphic microsatellite DNA markers from the marine gastropod Littorina saxatilis. Mol Ecol Notes 2:27-29

Swearer SE, Caselle JE, Lea DW, Warner RR (1999) Larval retention and recruitment in an island population of a coral-reef fish. Nature 402:799-802

Thorson G (1950) Reproductive and larval ecology of marine bottom invertebrates. Biol Rev Camb Philos Soc 25:1-45

Veliz D, Duchesne P, Bourget E, Bernatchez L (2006) Genetic evidence for kin aggregation in the intertidal acorn barnacle (Semibalanus balanoides). Mol Ecol 15:4193-4202

Watts PC, Thorpe JP (2006) Influence of contrasting larval developmental types upon the population-genetic structure of cheilostome bryozoans. Mar Biol 149:1093-1101

Weir BS, Cockerham CC (1984) Estimating F-statistics for the analysis of population structure. Evolution 38:1358-1370

Williams ST, Reid DG, Littlewood DTJ (2003) A molecular phylogeny of the Littorininae (Gastropoda:Littorinidae): unequal evolutionary rates, morphological parallelism, and biogeography of the Southern Ocean. Mol Phylogen Evol 28:60-86

Wright S (1978) Evolution and genetics of populations. Variability within and among populations, Vol 4. Chicago University Press, Chicago, IL

Submitted: July 18, 2007; Accepted: October 23, 2007 Proofs received from author(s): March 12, 2008 